\title{
A Three-dimensional Perspective on Wrongful Convictions in Israel: Organizational-Forensic, Psychosocial and Practical
}

\author{
Ronit Peled-Laskov ${ }^{*}$ and Efrat Shoham ${ }^{*}$
}

Ashkelon Academic College, Israel

\begin{abstract}
It is difficult to find an injustice committed against the citizen by the state that is greater than the conviction of an innocent person. At this stage, it may be tentatively stated that the phenomenon is not insignificant. This theoretical article describes the various aspects of the criminal justice system associated with the undesirable outcome of wrongful convictions. The paper reviews a series of organizational and forensic aspects that could bring about a bias in investigation of the legal truth. Furthermore, a number of psychosocial aspects relating to wrongful convictions, followed by practical aspects are described and discussed. It appears that on the practical level the phenomenon cries out for changes in the law enforcement system (e.g. implementation of the US Innocence Project or the biometric databank) and the need for empirical investigation. It appears that there is still a long way to go before a full understanding can be obtained of wrongful convictions and their prevention. One way or another, the authors are of the opinion that greater academic and public importance should be assigned to the question of wrongful convictions and perhaps turn the issue of truth and falsehood in criminal law into a theoretical and research field in its own right.
\end{abstract}

Keywords: Wrongful conviction, criminal justice system, innocent people, false confessions.

\section{INTRODUCTION}

The legal reality in which the law enforcement system operates in Israel, as in the Western world in general, contains instances of wrongful convictions of innocent individuals. In the USA, Anthony Ray Hinton was recently (2015) acquitted of the charge of murder, being the 153rd person in the history of this country to be acquitted after having been sentenced to the harshest of penalties - the penalty of death. According to Huff, Rattner \& Sagarin (1996), the number of wrongful convictions of innocent people in the USA ranges from one half to one percent of the total number of indictments. Ramsey \& Frank (2007) cite a higher number, namely, from one to three percent. Risinger (2007), whose estimation is based on data from the American "Innocence Project", claims that the number of wrongful convictions among those who were convicted of the combined offences of rape and murder and were sentenced to death lies between a minimum of 3.3 percent and a maximum of 6.6 percent.

A systematic study has yet to be conducted to assess the rate of wrongful convictions in Israel. Nevertheless, estimations made by Sangero \& Halpert (2014), show that the rate of wrongful convictions is five percent (for details see Sangero, 2014). According to the Central Bureau of Statistics (2014), the percentage of convictions in Israel out of the total number of indictments is $88.6 \%$ (in the past the Bureau

\footnotetext{
*Address correspondence to these authors at the Ashkelon Academic College, Israel; Tel: 054-6779883; Fax: 03-9733816; E-mail ronabi@netvision.net.il

Ashkelon Academic College, Israel; Tel: 08-6789232; Fax: 08-6789233;

E-mail: shoham@netzer.org.il
}

published the even higher figure of $99 \%$ ). Researchers (e.g. Sangero, 2014) maintain that this figure attests to the courts of law being only too ready to accept the position of the prosecution, leading to the possible conviction of innocent individuals. This claim is not shared by all researchers (Gezel, Galon \& Weinshell Margal, 2012; Levy, 2015).

According to Gezel et al. (2012), who conducted a study in collaboration with the Research Authority of the Judiciary, the rate of the total convictions in Israel is $70 \%$, indicating, in their opinion, that the courts of law do not always accept the prosecution's position. They state that many of the cases end in a decision to withdraw charges by resorting to a plea bargain or to partial conviction. In any event, they claim that the high percentage of convictions does not necessarily attest to the fact that the courts of law serve merely as a rubber stamp for the prosecution and could therefore be prone to error, but rather that because of limited resources they avoid trying many cases with a low probability of conviction and instead choose only "safe" cases. One way or another, the number of wrongful convictions in Israel and worldwide is unknown at any level of accuracy (Gezel \& Thor, 2009).

The Innocence Project, which was launched in the USA in the early 1990s, uses its website to update data on the number of convictions of innocent people. The rates of wrongful convictions is based on well-known cases ending in a conviction, although, as stated, the true extent of the phenomenon is not known and no accurate figures are available that can enable figures to be quoted accurately. The development and refinement of DNA tests have reinforced the suspicion that some 
of the convictions made by courts have indeed involved innocent individuals (Scheck, Neufeld \& Dwyer, 2000).

The desire to fight rising crime and accord the general public a sense of security, albeit delusional in a large number of cases, brings to the fore again and again the need existing in every democratic society to strike a balance between two fundamental protections: on the one hand protection of the civil rights of suspects charged with or convicted of committing a criminal offence; and on the other, the need to establish in the general public a sense of security and protection in its day-to-day activities. Achievement of a balance between these two factors brings into considerably sharper focus the built-in tension that exists between the two theoretical and normative models that govern the course of criminal procedures in democratic countries (Packer, 1968) - the Crime Control Model, whose basis is public interest in observance of the law and whose object is an economical and efficient legal system; and the Due Process Model, which is based on the desire to protect citizens from the exertion of excessively strong forces by the ruling authority and which aspires to a cautious legal system that conducts checks and balances in order to ensure credibility in its decisions (Shoham, 2010).

The Crime Control Model holds protection of the general public and preservation of social order to be key values. The operational word in this model is efficiency, namely, maximum utilization of the economic and social resources that are available to the law enforcement system for the purpose of effective supervision. The aim in the model is to shift the weight of the criminal procedures to the earlier stages of interrogation and detention in order to avoid prolonged and costly legal processes. An additional characteristic of the criminal procedure deriving from the Crime Control Model is uniformity and stereotypical treatment of detainees, enabling the system to handle a very large number of detainees in a relatively short period of time (Gezel, 2000; Lernau, 2001).

Efficiency (of time and resources) being a key element in the fight against crime in the Crime Control Model, efforts must be made to obtain a confession from the suspect already in the initial stages of the criminal procedure, thereby saving time and other costly resources. The success of the model is gauged by the number of cases ending in a conviction, as well as in maximum utilization and conservation of resources. Thus it is imperative to treat all detainees in a stereotypical and uniform manner. In general it may be stated that in countries with a high awareness of external and internal threats one may expect to find a predominance of the Crime Control Model (namely, greater legitimacy to the existence of false positives with respect to criminal procedures and violation of individual rights) (Shoham, 2010). The proportion of false positives to negatives has gained the epithet "Blackstone ratio", reflecting the degree of certainty required by the legal system before convicting a suspect (Keijser, Lange, Evianne \& Wilsem, 2014).

Standing in contrast to the Crime Control Model is the Due Process Model. This model, which views credibility as being a key factor in the workings of the law enforcement system, seeks to strike a balance between the inherent helplessness of the citizen and the practically unlimited power of the law enforcement system. According to the Due Process Model, both the police and the prosecution are perceived as interested parties, as a result of which the focal point of decisionmaking throughout the criminal procedure must be shifted to the court of law, which is perceived as a neutral entity that is not given to favoritism. The investment of time and resources in the investigation of criminal events is perceived as a prerequisite for the existence of a just and credible criminal procedure. According to this theoretical model it is preferable for a person who is guilty of having committed an offence to be freed than for a person who did not commit an offence to be wrongfully convicted (Kitai, 2003).

The concept of wrongful conviction has negative connotations: serious harm to innocent persons, negligence and perhaps even corruption in the law enforcement system, as well as betrayal of the trust that the public places in law enforcers in particular, and the ruling authority in general. There is no greater injustice than conviction of an innocent person.

The aim of this theoretical article is to describe the various aspects of the criminal justice system associated with the undesirable outcome of wrongful convictions. This descriptive paper will review a series of organizational and forensic aspects that could bring about a bias in investigation of the legal truth. Furthermore, a number of psychosocial aspects relating to wrongful convictions, followed by practical aspects will be described and discussed.

\section{ORGANIZATIONAL AND FORENSIC ASPECTS REL- ATING TO INVESTIGATION OF THE LEGAL TRUTH}

Gilboa (2012) points to legal developments that have taken place in recent years which in his opinion 
have steered the court away from its attempts to expose the truth.

These developments include, among other things, the concept prevailing in Israel's legal system that a balance must be achieved between the value of truth and numerous other values such as the fundamental rights of an individual or the value of justice. Gilboa indicates that these developments burden investigators with a greater responsibility to expose the truth, especially in light of the fact that mistakes made in the initial stage of the criminal procedure - the investigation stage - tend to be difficult to correct or are even perpetuated in later stages. Because of the similarity between criminal investigation and scientific research, Gilboa suggests adopting the methods used in scientific research, with special reference to the skepticism that marks it, in anticipation that it will help to lower the rate of wrongful convictions.

Sangero \& Halpert (2012) stress the danger invoIved in the legal establishment of instruments of enforcement since in their opinion judges do not have sufficient technological or electro-optic knowledge on which to base their convictions. Expert opinions that are presented to judges are never uniform and are even at times contradictory, and it is the judge who in the final analysis decides what to accept and what to reject. Sangero states the need for also adopting cautionary measures in all matters pertaining to the manufacture and approval of instruments of enforcement that produce scientific evidence based on which fates are sealed. The dependence of criminal law on forensic evidence is high despite the findings of studies that show that instruments of enforcement serving experts today are not sufficiently reliable or safe (Sangero \& Halpert, 2012; Sangero, 2014).

Today, according to Sangero, the manufacturer of an instrument producing scientific evidence that serves as the sole basis for incarceration is not subject to any safety requirement. This is in contrast to the stringent testing that other instruments undergo, such as those employed in medical diagnosis, before they are approved for use. It is claimed that if the instrument is suitable for the medical profession, all the more reason for it to be suitable for law enforcement.

One of the prominent issues in the theoretical literature regarding wrongful convictions has to do with the conviction of an accused based on a single piece of evidence, such as DNA or fingerprints. A single piece of evidence can be confession by a suspect or testimony by a single eye witness. It has been proved that confessions have at times been made by suspects because of the conditions of detainment or mental stress, so that the legal system should not be allowed to base its decisions on evidence of this nature. Finally, the US Innocence Project, which resulted in the acquittal of many who had been convicted for offences they had not committed, adding that one cannot know how many had been convicted thus and were simply not lucky enough to prove their innocence (Sangero, 2014; Sangero \& Halpert, 2012).

It appears that the legal system, which is frequently based on a single eye witness, is in need of tools to evaluate the reliability of evidence in addition to the methods (both physical and psychological) that are in current use. Dilmon (2012) proposes a unique way to diagnose false testimonies made by offenders, namely, linguistically. This method is based on studies that were conducted in Hebrew and other languages in which distinctions were found between truthful and false dialogue according to various linguistic indices. The results of the studies attest to the effectiveness of the linguistic tool and the potential for its future use in diagnosing evidence suspected to be false.

From various studies conducted (for details see Gould \& Leo, 2010) an impressive list of factors can be cited that are likely to bring about wrongful convictions. These factors, which are of an organizational-legal nature, include distortion of evidence by the police, avoidance on the part of the police to investigate other directions, and false confessions. Other factors include erroneous expert opinions presented by forensic specialists, misleading circumstantial evidence, the level of representation of the accused, errors made by judges, and public pressure. Some also claim that the law enforcement system produces wrongful convictions because both the police and the prosecution have incentives to arrive at a conviction, with too little encouragement given them to convict the right person (Koppl \& Sacks, 2013).

As stated, a significant factor that could result in a wrongful conviction is false confession. The theoretical and research literature dealing with the issue of wrongful convictions catalogues a large number of internal and external factors, whether rational or otherwise, that could result in a person admitting to an act he did not commit (Gudjonsson et al., 2012; Drake, Gudjonsson, Sigfusdottir, \& Sigurdsson, 2014). Lately, cracks have appeared in the status of confession as the "queen of evidence" in criminal law. Sangero 
(2005) for example, refers to confession not as the queen of evidence but rather as the "empress of wrongful convictions". This change of status in Israel has taken place thanks, among others, to the Goldberg Committee (1994) as well as perhaps to research studies that show that the ability to distinguish between a false confession and a truthful confession is limited (Honts, Kassin \& Craig, 2014).

Verdicts published in recent years suggest that various factors exist that could lead to a false confession on the part of a suspect in a criminal offence. Among these are the desire to cover up for a person who had committed the act; pressure on the part of various organizations to confess to the deed even though the accused is innocent; the impact of the investigation and detainment (for details see below); and interrogators who are unreliable and operate based on a variety of personal interests (Cutler, Findley \& Moore, 2014; Leo \& Deborah, 2010).

Plea bargains can also affect the truth. An innocent person could confess to partial guilt for fear that he will lose the case altogether. This does not necessarily mean that plea bargains are based on falsehoods, although they do suppress investigation of the truth. It may be said that if plea bargains have an adverse effect on the truth, then the commoner the practice of plea bargains becomes, the greater the concern that the value of truth in a criminal case will be eroded (Gross, 1997; Mizrahi, 2003).

As stated, errors are not the exclusive domain of the police, the prosecution or the witnesses. Judges too can and do make mistakes. As far back as the 1950s Supreme Court Judge Agranat asserted that "No legal system exists in any country, nor has any been created, that can operate to perfection, without mishaps, while dispensing absolute justice in each and every case. Judges, by virtue of the fact that they are human, can make mistakes from time to time." In the same vein, Judge Haim Cohen wrote (1990, p. 121): "As long as judgment is entrusted to flesh and blood it is impossible to prevent mistakes. Not only witnesses, but judges too suffer from human limitations, which could adversely affect the determination of factual truth: a judge too is flesh and blood and is not immune to any human weakness, a judge too, like all people, has prejudices, religious or philosophical beliefs of one kind or another, and he generally does not stop to think what the source is of his opinion and attitude and what is truly objective in them."
Various studies have found a correlation between personal characteristics and the ability to judge the trustworthiness of evidence (Granhag \& Stromwall, 2000; Nahari, Glickson \& Nachson, 2009; Jackson \& Granhag, 1997). Personal characteristics could refer to the personality of the evaluator, the jurisdictional context in which he is acting, his interpretations, etc., all of which could ultimately lead to differing judicial conclusions. It may therefore be concluded that judicial decisions that are influenced by a variety of factors cannot be as fully objective as they are intended to be. Such factors could lead to biased judgment, the impact of which could be especially critical in cases where the evidence is assigned substantial importance or is regarded as the sole evidence in making a ruling.

The adversarial nature of the legal system practiced in Israel also contributes to the likelihood of wrongful convictions. This system, in which the judge is passive vis-à-vis the prosecutor and the defense attorney, is particularly common in countries that have inherited the British legal system (including, to a certain extent, Israel). According to this system the judge or jury serves as a passive ruling body based on facts and allegations brought before them by the litigants, and do not take an active part in the search for facts and legal rules that must be applied in the case under consideration. Contrasting with this is the inquisitorial system, common in countries practicing Continental law, also known as "civil law". In the inquisitorial system the judge takes an active part in the investigation and can unearth facts that the litigants choose not to bring before him (Barak, 1996; Sangero \& Kremnitzer , 1999).

An additional contribution to wrongful convictions may be found in the legal system itself. In general, it is possible to envisage a legal system that consists of two poles, where each pole has the potential for wrongful convictions. At one pole the formalistic approach to law can be identified and at the other the realistic-critical approach. According to the formalistic approach, the law is composed of a system of rules which every judge is expected to apply to the web of facts brought before him. Legal formalism aspires to a condition in which any factual situation underlying a legal dispute can be assigned to a category in which the suitable solution exists (Mautner, 1993, 2006).

A judge, like any other person, has standpoints with respect to matters of ethics. According to Frosh (1990), a judge's personal ethics includes beliefs relating to the conduct of a person as an individual, to social policy 
and to social institutions. This leaves its stamp on the many decisions that he makes in his life. According to him, judicial decisions must rest only on objective criteria, of the kind that a judge can identify and pursue without having to grapple with ethical questions. According to the "wild horse" theory only objective criteria can guide the judge; in other words the judge who has to cope with ethical questions in the framework of his duties and takes into consideration the personal views he holds in connection with these questions, may be likened to a person riding a wild horse (Frosh, 1988).

In the late 19th century Judge Holmes (Holmes, 1920) expressed his opposition to the formalistic approach to law. According to him, a gap exists between what is written in the Legal Code and what is implemented in practice. Law, in his opinion, is what courts do and not what is written in law books. In Holmes's wake the realistic stream developed in the second and third decades of the 20th century, spawning the critical approach in the 1970s.

According to the critical approach, the formalistic approach to law is a myth and there is no scientific way to derive the truth. Legal rules are subject to different interpretations, leading to different conclusions, and these interpretations depend on the interpreter, namely, the judge, his social background and his moral standpoints (Salzberger, 2000). The judge is an interpreter, states Barak (1982), his aim being to express the meaning of the norm. The law determines the norm, whose boundaries are determined by the judge. According to Judge Alon (2003) the phenomenon of pluralism is welcomed and any view or expert opinion of a judge is worthy and enhances the greatness of the judicial system.

The realistic approach emphasizes the creativity of the judge. In a situation where the law is unclear the judge must create a law. In other words, the role of the judge is legislative and in this capacity, the judge exercises full discretion. He takes into consideration social consensus, as does the legislator (Barak, 1987). Judge Barak views limited judicial discretion as the appropriate model. In his opinion, a judge must not think as a legislator. He must take into account a variety of considerations, based on which he must formulate judicial policy. He creates law in the course of judgment, using limited judicial discretion (Barak, 1987).

Irrespective of the legal approach, judicial decisions are often based on common sense. According to
MacCrimmon (2001), in order to understand the processes by which verdicts are reached and sentences passed it is essential to examine the role of common sense in general, and its use in the legal context in particular. According to Allen (2001), the stuff that makes up common sense changes with time and is subject to differing interpretations. And since judicial decisions are often based on common sense, miscarriage of justice can occur.

Judicial procedures can include human error caused by gleaning erroneous information, ignoring information, holding inconsistent beliefs, and other factors (Zelig \& Nachshon, 2012; MacCrimmon, 2001). According to Mautner (1998), common sense is a subcategory of culture. Whereas culture is a system that is fixed in place by human creativity in general, common sense is an intangible cultural system that contains empirical and normative information on the world, through which it is possible to function properly on a day-to-day basis in a given social group. Common sense includes informal knowledge that humans have acquired on the ways in which the social and natural world operate and on what can be considered appropriate in relations between people (Zelig \& Nachshon, 2012). It may be tentatively claimed that the critical system involves relatively more use of common sense since it calls for discretion to a greater extent than does the formalistic approach. This being the case, it may be concluded that the critical approach is more prone to cognitive judicial biases of the kind described by Zelig \& Nachshon (2012).

The formalistic approach leads to consistency in judgment and thus upholds the basic right to equality, which calls for equal treatment in equal cases - one of the fundamental tenets of law. On the other hand, legal norms alone do not always offer a definitive solution to disputes in which a judge is required to rule (Frosh, 1988). An additional disadvantage stems from the fact that any factual situation underlying a legal dispute can be assigned to a category in which the appropriate solution can be found. As a result of organizing law in this manner, the process by which the ruling is made is technical (Mautner, 1993, 2006). And being technical, it can also lead to the conviction of innocent persons.

The critical approach to law is more humane; in the words of Mautner (2006), when dealing with human beings and humane issues it is proper to consider the implications of decisions on human lives, requiring the judge to exercise discretion and choice with regard to the sources he uses in arriving at his ruling. It is 
precisely the system that operates on a relatively low level of formalism that could result in a better application of ethical principles (Mautner, 1993). On the other hand the main disadvantage in the approach is that it could lead to a lack of consistency in judgment and to a sense of justice being absent. Reflection on the part of the judge, as with any person, involves principles of ethical judgment, which are influenced by his subjective world. In order to reach a verdict and pass sentence, the judge considers various issues and assigns them importance based on his perceptions. In addition, since judicial decisions made according to this system are often based on common sense, which is unsystematic (Geertz, 1983), miscarriage of justice is possible.

As regards wrongful convictions, here too lies a danger. The moment there is leeway for use of discretion on the part of the judge factors can be introduced that inherently involve differential treatment towards individuals in accordance with the judge's world view. Such a situation can in turn lead to the conviction of innocent persons. It appears that both the legal approaches have the potential to lead to wrongful convictions, although it is possible to treat erroneous actions against the background of the critical approach with greater understanding due to the fact that it is intrinsically more humane.

\section{PSYCHOSOCIAL ASPECTS OF WRONGFUL CON- VICTIONS}

\section{Psychological Aspects Behind Law Enforcer's Activities}

The literature describes several cases common to which is the conviction of suspects based on their confession to offences they did not commit. Much has been written in the literature on false confessions and the reasons for making them, and in particular on the processes and factors influencing the suspect to confess to an offence he did not commit (Cutler, Findley \& Moore, 2014; Kassin, 2015; Yehosha-Stern \& Carmon, 2012). In order to understand why criminal suspects submit false confessions it is important first to understand how and why police interrogators focus on psychological aspects in order to arouse the mental need on the part of the suspect to make a confession that is at times false.

Yehosha-Stern \& Carmon (2012) turn the spotlight on the modus operandi and viewpoint of the interrogator during the course of the interrogation. With this focus, the authors present the position according to which a number of psychological components external and internal - exist that could influence the work of the interrogator, and at times direct or misdirect it such as to result in extraction of a false confession from the suspect. Kassin (2015), who deals with the social psychology of false confessions, reviews laboratory and field researches that attempt to track Milgramesque processes in police interrogations and the methods by which innocent people are made to confess. He also refers to the decisive impact that such confessions have on the judges, the jury, witnesses and expert witnesses. Against this background it is suggested to record the interrogations and bring experts in confessions as witnesses to court (Kassin, 2015).

In dealing with the suspect himself, Kassin (1997, 2015) classifies false confessions into three principal categories: spontaneous, voluntary false confessions obtained without any external pressure; false confessions obtained by coercion through the application of severe pressure during the course of the interrogation; and false confessions obtained through a process of internalization using various suggestive techniques.

Leo (2009) suggests possible reasons for people willingly submitting false confessions: a pathological need for fame, a desire to impress a particular person or protect a friend or family member, and a conscious need to come to terms with guilt and atone for previous offences by self-punishment. False confessions obtained against the background of coercion are explained principally by the desire of suspects to end the ordeal of the interrogation and submit. As regards the third type, the conditions to which an innocent suspect is subjected - with suggestive tactics being used by the interrogator on the one hand, and with the suspect himself being in a state of anxiety, fatigue, stress and confusion - cause him to start believing that he did indeed commit the crime. In addition, the suspect's memory is liable to change to the extent that the original content is wiped out. Evidence exists of the power that misinformation fed to the suspect during the course of interrogation has to effectively alter reports on the event as recorded in his memory (Redlich, Summers \& Hoover, 2010). Redlich et al. compare the process of interrogation to hypnosis. They claim that interrogation can create a situation much like a trance, with enhanced suggestion used with the suspect, such that truth and falsehood become confused in his mind.

The ability to withstand unrelenting interrogation is limited. A worn-out suspect who is forced to cope with 
a lack of sleep over an extended period of time eventually suffers burnout, to the point where even a hardened suspect will admit to an offence he did not commit (Redlich, et al., 2010). Barg (2012) refers to the connection that exists between the mental and physical stress to which a person is subjected during interrogation, physical ailments and false confessions. $\mathrm{He}$ also refers to the role played by mental makeup, fear of risk-taking, and erroneous profit and loss considerations in bringing a suspect to agree even to a plea bargain despite his innocence (Barg, 2012).

Although the findings of research studies suggest that weak populations exist (minors, retardates, introverts, the mentally disturbed, people with behavioral disorders and those with ADHD) that are more vulnerable to making false confessions (Gross et al., 2005; Gudjonsson, Sigurdsson, Sigfusdottir \& Young, 2012), although false confessions are commonplace even among normal individuals, including those with average and high intelligence (Horseelenberg et al., 2006). Gilboa (2008) claims that people on the fringes, representing different and reviled segments of the population, are more susceptible to making false confessions. According to him marginal people are more prone to submit to manipulation and influence by the police interrogator and are more helpless in the face of interrogation pressures by the police, even if the latter do not exceed the boundaries stipulated by the court.

Zelig \& Nachshon (2012) too refer to the work of the interrogator. The authors raise a troubling issue relating to the natural tendency among people to make cognitive errors, namely, errors in perception, memory, thinking and judgment. Since police interrogation is based on processes of reflection and deduction, and since it has numerous implications in terms of the lives of witnesses, suspects and police officers, the need arises to identify such skews. The authors also recommend putting in place properly organized writing procedures, including drafting of deductions in the form of arguments. Such writing can help in identifying missing information and baseless claims that were woven into the deduction processes.

Various studies have focused on psychological aspects in the interrogation of eye witnesses (Bernstein \& Loftus, 2009; Koessler, Engler, Riether \& Kissler, 2009; Skagerberg \& Wright, 2008). The studies point to a series of internal and external factors that can affect a witness's memory, among them his cognitive abilities, social proclivities, mental state and stereotypical perceptions. In addition, research has found that the memory of eye witnesses may be influenced by the interrogator's manner in conducting the investigation. Leading questions and misinformation have a significant impact on memory, to the extent that witnesses can report on incidents that never took place (Shechory, 2012). These and other findings show that the memory of individuals under investigation can be manipulated, while it can also be influenced by their personality traits such as suggestibility, conformity and authoritativeness, as well as their emotional states (Bernstein \& Loftus, 2009; Ceci \& Bruck, 1996; Skegerberg \& Wright, 2008).

The literature refers to an additional psychological obstacle to arriving at the truth in a path strewn with difficulties, namely, a situation in which an eye witness is required to identify a suspect in a lineup that includes innocent people (Jackiw, Arbuthnott, Pfeifer, Marcon, Meissner, 2008; Catz, 2012; Wells \& Olson, 2001, 2003). There are at least two kinds of factors affecting the identification of eye witnesses: organizational and situational. The organizational aspects are dictated by the legal system, e.g. the number of innocent people included in the lineup (Wells \& Olson, 2003); in contrast, the situational aspects depend on the scene of the crime and are not under the individual's control, e.g. the amount of time he was exposed to the criminal's face (De Jong, Wagenaar, Wolters \& Verstijnen, 2005).

One situational factor affecting the accuracy of identification in a lineup is ethnic bias (Catz, 2012). This can seal the fate of a person in the sense that an eye witness can identify the faces of persons of his race more quickly and accurately than those belonging to other races (Gross, 2009; Meissner \& Brigham, 2001). In many cases the court relies on the testimony of eye witnesses and therefore identification of the suspect in a lineup is a very important part of the legal process. Indeed, in many cases such identification serves as the only piece of evidence in identifying the accused and even in convicting him. An understanding of the factors influencing identification by eye witnesses, including ethnic bias, should help the court in determining the credibility of the witnesses, leading to a reduction in wrongful convictions.

\section{Psychological and Social Implications of Wrong- fully Convicted Persons}

Although this article on the whole addresses the attempt to understand the processes leading to 
erroneous decisions regarding guilt, attention must also be paid to the fact that wrongful convictions have severe psychological and social implications with respect to the person who is wrongfully convicted.

Apart from the considerable damage done to a good reputation and the massive financial investment that a person must at times make in his own legal defense, a wrongful conviction is accompanied by strong feelings of helplessness, umbrage, betrayal, anger, frustration and consuming fear (Konvisser, 2012).

A wrongfully convicted individual who has been freed from prison does not generally participate in rehabilitation programs and returns to society without any guidance or support (Cobbina, Huebner \& Mark, 2010). He is compelled to face a host of difficulties, among them a battle with the authorities responsible for matters such as cancellation of the conviction, formal recognition of the injustice done to him and the disability caused him as a result, and receipt of compensation from the state. In addition, he must face an environment that at times still regards him as an offender, this clearly being dependent on whether the true offender has been identified, with the legal system making a public announcement of having erred and apologizing (Konvisser, 2012).

An additional difficulty is finding work. By and large employers do not want to take the risk of hiring such a person, and he must cope with social ostracism and stigmatization (Konvisser, 2012). It appears that the stigma applied to the wrongfully convicted is no different from that applied to offenders (Kimberley \& Leach, 2015a). Kimberley \& Leach (2015b) attempt to check whether differences exist in the way society perceives different types of wrongfully convicted individuals and found that those who confessed to an act that they did not commit, e.g. persons who were wrongfully convicted because of mistaken identification by eye witnesses, are perceived by society in a more negative light than others.

The social price that the wrongfully convicted person must pay is not confined to only the reaction on the part of the social environment - it is claimed (Case Western Reserve Law Review, 2013) that he is not entitled to compensation because he is perceived as having contributed to his own conviction. In other words, such victims could be doubly victimized.

While mental injury caused to prisoners of war or accident victims has been the subject of in-depth research and extensive documentation, few studies have examined the psychological effects of wrongful convictions on the victims. Convicted persons who have had to do time in prison are compelled to cope with "prison pains" just like other prisoners, but since they are the victims of injustice, an extra dose of adaptation is required (Konvisser, 2012). A research study that examined 18 individuals who were acquitted and freed pointed to the fact that their personality had changed, with post-traumatic stress disorders and depression being observed in them. The freed individuals reported psychological difficulties and difficulties in social adjustment, particularly in close relationships. Behaviors such as self-destruction, drug abuse and alcohol consumption were also observed (Adrian, 2005).

Similar findings were reached by Wildeman, Costelloe \& Schehr (2011), who interviewed 55 wrongfully convicted subjects and found that some of them suffered from a combination of several mental disorders together. They note, however, that employment moderates the severity of the affliction. Jeffrey \& Ashley (2008) compare the trauma experienced by wrongfully convicted individuals to that suffered by shell-shocked soldiers or prisoners of war. Both are liable to experience depression, anxiety, helplessness, sleep disorders, apathy, difficulties in adjustment, and guilt feelings, or suffer from various mental disturbances such as dissociative disorders, dysthymia or PTSD. Konvisser (2012) refers to the unique psychological effects of wrongful convictions on women who were sent to prison on various criminal charges, such as causing the death of infants (as a result of the shaken baby syndrome), and proposes ways to cope with them.

\section{PRACTICAL CONSIDERATIONS IN INVESTIGATION OF THE TRUTH}

A theoretical discussion attempting to understand the origins of wrongful convictions during the criminal procedure should also considerate the mutual point of view; theoretical and practical. While the literature deals extensively with theoretical aspects organizational, forensic, psychological and social - it appears that practical aspects have received only limited attention (Lernau et al., 2012). In Israel too, only a small number of studies have sought to address practical aspects (e.g. Ish- Shalom, 2012; Lernau et al., 2012; Sangero, 2014; Zemrion-Helek, 2012).

Zemrion-Helek (2012) explains the meaning of miscarriage of justice and focuses on the phenomenon in interrogation, with the emphasis on the fact that it is 
both egregious and special. She reviews the causes of miscarriage of justice in interrogations and focuses on violation of the suspect's rights. Factors such as violation by interrogators of the right to remain silent, the right to meet with a lawyer and the right to confer are cited. Zemrion-Helek (2012) intersperses examples from the field showing how these factors are manifested in practice.

Practical solutions to prevent wrongful convictions were also proposed by Sangero (2014). The first is downgrading of the status of the confession: "When one errs in thinking that confession is strong evidence, and when one is ready to convict on the basis of this alone, it is no wonder that the efforts of police investigators are channeled principally in an attempt to extract confessions from suspects" (Sangero, 2014, p. 71). Sangero presents a number of arguments to explain this. To begin with, the confession is still considered (mistakenly, in his opinion) crucial evidence. In addition, a key index by which to gauge police successes in Israel and in the Western world in general, as well as the success of the prosecution, has always been the percentage of convictions. This factor has also served to advance interrogators and even prosecuting attorneys. Gathering of confessions is considered to be easy and inexpensive as compared with alternative investigative methods. Judges do not generally reject confessions, thus conveying the message that the method used by investigators to extract confessions from suspects is acceptable.

Despite the amendment to the Detention Law, which was intended to limit the use of detention as a means of carrying out interrogations and redefine proper detention conditions, judges in Israel allow the police to routinely use detention under appalling conditions or threats during detention as a means to pressure suspects into confessing (Lernau, 2001). It appears that unlike the Due Process model, which regards the suspect as innocent until proven guilty, the police in Israel acts in many cases according to the erroneous assumption that the suspect is guilty and that evidence must be found to accuse him.

Sangero proposes different methods that will allow the system to free itself from the destructive concept of guilt on the part of the suspect. First of all, it is important to be aware that the concept exists. Secondly, the concept and its erroneous results must be avoided in the training given to police interrogators, prosecuting attorneys and judges. It must be emphasized to police interrogators that their job is not to crack the case at all costs but to help the court to arrive at the truth and ensure that justice is done. Accordingly, if it is in their power to discover and reveal a piece of evidence that supports acquittal of the suspect, it is their duty to do so. Thirdly, police investigators must be encouraged to pursue several directions in their interrogations and not focus only on the suspect they have apprehended and attempt to make him confess. Similarly, it is important to commend and advance not only an investigator who has succeeded in gathering evidence incriminating the suspect but also one who has exposed the truth and prevented an innocent person from being tried. Fourthly, the prosecuting attorney must oversee police investigations and where necessary point out additional investigative angles. The work of prosecuting attorneys must also be supervised. Fifthly, it is desirable to include in every team investigating a serious crime an investigator whose job it will be to "swim upstream", namely, look for evidence of the suspect's innocence, thus enriching the investigation by making it more comprehensive. The erroneous concept of the "suspect's guilt" is misleading and boosts parties, among them in the final analysis the courts of law, who are anxious to convict innocent individuals.

The legal dynamic during the trial and the feeling of "conviction at any cost" are also cited as factors in wrongful convictions. Lernau et al. (2012) examined the issue of conviction of innocent person from a unique angle. They describe the legal system from the viewpoint of the defense attorney in attempting to illustrate to the reader the dynamic in the court and the feeling of "conviction at any cost" that accompanies the authors during the course of a trial. Lernau et al. propose explanations for this dynamic, referring to the tension prevailing between the "possession of innocence" which criminal law is so disposed to touting, and the mechanisms that lead to the creation of "possession of guilt" according to which elements in the criminal system act, under the assumption that the suspect or accused is already guilty.

They claim that possession of guilt in courts of law is based on the assumption that police investigation is objective and based on a well thought-out procedure of inquiry into all the relevant facts, whereas in reality pretrial procedures are influenced by the possession of guilt and investigators are overzealous in their attempt to find incriminating evidence, rooted perhaps in the belief that the prosecution and the courts will in any event conduct a thorough examination of all the evidence. And indeed, the authors emphasize, most of the wrongful convictions can be characterized as a failure on the part of the legal system to identify errors 
that were made somewhere at the outset, before the point of no return.

\section{IN SUMMATION}

It is difficult to find an injustice committed against the citizen by the state that is greater than the conviction of an innocent person. At this stage, it may be tentatively stated that the phenomenon is not insignificant. In Israel and elsewhere disclosures are made from time to time of the conviction of innocent persons, these disclosures apparently being only the tip of the iceberg. The DNA revolution and the US Innocence Project have led to the acquittal of prisoners who had been convicted of the most serious crimes and who had been sentenced to the most severe punishments. It appears that on the practical level the phenomenon cries out for changes in the law enforcement system (e.g. in the vein proposed by Sangero, 2014) and for implementation of the US Innocence Project in Israel and other parts of the world as well. A biometric databank, despite its drawbacks, can help to some extent in undoing injustices. On the other hand, it can also increase the likelihood of wrongful convictions through the use of fingerprints. Nevertheless, it can serve as fertile ground for research studies that will contribute to a broader understanding of errors and their prevention. On the academic level, it appears that there is still room for a wider research regarding different perspectives of this subject, leading to a more extensive empirical base.

The present article has reviewed literature relating to different aspects accompanying the actions of the law enforcement system in arriving at the undesirable outcome of wrongful convictions. It appears that there is still a long way to go before a full understanding can be obtained of wrongful convictions and their prevention. The present article demonstrates the need for empirical investigation of laboratory research studies, such as those conducted by Kassin (2015), who examined investigative techniques that raise the likelihood of confession, and showed that the confession in practice has the power to change perception and interpretation vis-à-vis other evidence. In addition, the verification of the correlation between personal characteristics and the ability to judge the trustworthiness of evidence by the quantitative methods can significantly increase interest of criminologists.

Qualitative interviews between investigators and suspects can also serve as a rich source of material for researchers. Through them researchers will be able to present common themes that include the reasons for wrongful convictions, personality traits and social status of convicted persons, experiences from detention periods, from the trial, from prison and from discharge. Through qualitative research it will perhaps also be possible to identify and map the weaknesses of the law enforcement system in a given cultural and political framework. One way or another, the authors are of the opinion that greater academic and public importance be assigned to the question of wrongful convictions and perhaps turn the issue of truth and falsehood in criminal law into a theoretical and research field in its own right.

\section{REFERENCES}

Adrian, T. G. (2005). Understanding the effects of wrongful imprisonment, Crime and Justice, 32, 1-58.

Allen, R. J. (2001). Common sense, rationality and the legal process law. Cardozo Review, 22, 1417-1431.

Alon, M. (2003). The True Law of Truth. In A. Barak (Ed.), Shamgar Book - Articles, Part 2 (p. 391-421). Tel Aviv: The Bar Publications.

Barak, A. (1982). On the Judge as Interpreter. Law, 12, 248-257.

Barak, A. (1987). Jurisdictional Discretion. Tel Aviv: Papyrus.

Barak, A. (1996). On Law, Jurisdiction and Truth. Law, 27, 11-16.

Bedau, H. A., \& Radelet, M. L. (1987). Miscarriages of Justice in Potentially Capital Cases, Stanford Law, 40, 21-179. http://dx.doi.org/10.2307/1228828

Barg, Y. (2012). Reflections on False Confessions and Plea Bargains. In R. Peled-Laskov, E. Shoham and M. Carmon (Eds.), Wrongful Convictions: Philosophical, Psychological and Organizational Aspects (p. 315-330). Tel Aviv: PerlsteinGinossar Publications.

Bernstein, D. M., \& Loftus, E. F. (2009). How to tell if a particular memory is true or false. Perspectives on Psychological Sciences, 4, 370-374. http://dx.doi.org/10.1111/j.1745-6924.2009.01140.x

Case Western Reserve Law Review (2013). Re-punishing the innocent: false confession as an unjust obstacle to compensation for the wrongfully convicted. Volume, 63, 1393-1418.

Ceci, S. J., \& Bruck, M. (1996). Jeopardy in the courtroom: A scientific analysis of children's testimony. Washington: American Psychological Association.

Central Bureau of Statistics (2014). Statistical Yearbooks in Israel 6365 (2012-2014). The Face of Israeli Society. Report No. 6.

Cobbina, J. E., Huebner, B. M.,. \& Mark, T. (2010). Men, Women, and Post release Offending: An Examination of the Nature of the Link Between Relational Ties and Recidivism. Crime and Delinquency, 20, 1 - 31 .

Cohen, H. (1990). "Just" Punishment: Deliberations Following Rulings. Criminal Law, 1, 19-27.

Cutler, B., Findley, K.A., Moore, T.E. (2014). Interrogations and False Confessions: A Psychological Perspective. Canadian Criminal Law Review, $18,153-170$.

De Jong, M., Wagenaar, W. A., Wolters, G., \& Verstijnen, I. M. (2005). Familiar face recognition as a function of distance and illumination: a practical tool for use in the courtroom. Psychology, Crime and Law, 11, 87-97. http://dx.doi.org/10.1080/10683160410001715123

Dilmon, R. (2012). Linguistic Diagnosis of Suspect Testimony - True or False? In R. Peled-Laskov, E. Shoham and M. Carmon 
(Eds.). Wrongful Convictions: Philosophical, Psychological and Organizational Aspects (p. 95-111). Tel Aviv: PerlsteinGinossar Publications.

Drake, K. E., Gudjonsson, G. H., Sigfusdottir, I. D., Sigurdsson, J. F. (2014). An investigation into the relationship between the reported experience of negative life events, trait stresssensitivity and false confessions among further education students in Iceland. Personality and Individual Differences, 9, 135-140.

Forst, B. (2004). Errors of Justice: Nature, Sources and Remedies. New York: Cambridge University Press.

Frosh, E. (1988). The Place for Considerations of Justice in Rulings by the High Court of Justice. Law Leaves, 13, 453-498.

Frosh, E. (1990). Wild Horse Theory, Remoteness of the Judge's Discretion and His Personal Ethics. Criminal Law, 19, 325368.

Geertz, C. (1983). Common sense as a cultural system. In H.L. A. Hart (Ed.) Essays In jurisprudence and philosophy (pp. 7278). London: Local Knowledge.

Gezel, O. (2000). The Tests for Rejecting the Plea Bargain. The Defence Counsel, 37, 1-9.

Gezel, O., Galon, I., \& Weinshell- Margal, K. (2012). Lessons in Conviction (Acquittals in Criminal Procedures). Haifa University and the Research Department of the Judiciary.

Gezel, O., \& Thor, A. (2009). The effect of innocence on plea bargains: empirical findings, psychological insights and normative implications. Law, 39, 115-153.

Gilboa, M. (2008). Is the Crown of the "Queen of Evidence" Falling? Syndrome of the Fringe Group Making False Confessions Victims of the Law Enforcement System. In Y. Kim, Y. BarZohar and E. Levy. Victims of Law Enforcement, Sex and Society (35-101). Tel Aviv: Masada Publishers.

Gilboa, M. (2012). Scientific Investigation and Research - Or the Heightened Responsibility of the Researcher in Exposing the Truth in Criminal Procedure. In R. Peled-Laskov, E. Shoham and M. Carmon (Eds.). Wrongful Convictions: Philosophical, Psychological and Organizational Aspects (p. 3-53). Tel Aviv: Perlstein-Ginossar Publications.

Gould, J. B., \& Leo, R. A. (2010). "Justice" in action: one hundred years later wrongful convictions after a century of research. The Journal of Criminal Law and Criminology, 100, 825-868.

Granhag, P. A., \& Stromwall, L. A. (2000). Effects of preconceptions on deception detection and new answers to why lie-catchers often fail. Psychology, Crime \& Law, 6, 197-218. http://dx.doi.org/10.1080/10683160008409804

Gross, E. (1997). Investigation of the Truth and Jurisdictional Oversight: Intervention by Instances of Appeal in Factual Findings. Law Review, 20, 587-588.

Gross, T. F. (2009). Own-Ethnicity bias in the recognition of black, east Asian, Hispanic, and white faces. Basic and Applied Social Psychology, 31, 128-135. http://dx.doi.org/10.1080/01973530902880381

Gross, S. R., Matheson, J. K., Montgomery, D. J, Sujata, P. (2005). Exonerations in the United States, 1989 through 2003. Journal of Criminal Law and Criminology, 95, 523-560.

Gudjonsson, G.H. (2003). The psychology of interrogations and confessions: a handbook. New York: John Wiley \& Sons.

Gudjonsson, G. H., Sigurdsson, J. F., Sigfusdottir, I. D., \& Young, S. (2012). False confessions to police and their relationship with conduct disorder, ADHD, and life adversity. Personality and Individual Differences, 52, 696-701. http://dx.doi.org/10.1016/i.paid.2011.12.025

Holmes, O. W. (1920). Collected legal papers. New York: Harcourt, Brace and Company.

Horselenberg, R., Merckelbach, H., Smeets, T., Franssens, D., Peters, G. Y., \& Zeles, G. (2006). False confessions in the lab: Do plausibility and consequences matter? Psychology, Crime \& Law, 12, 61-75. http://dx.doi.org/10.1080/1068310042000303076
Honts, C.R., Kassin, S.M., \& Craig, R.A. (2014). 'I'd know a false confession if I saw one': a constructive replication with juveniles. Psychology, Crime \& Law, 20(7), 695-704. http://dx.doi.org/10.1080/1068316X.2013.854792

Huff, C., Rattner, A., \& Sagarin, E. (1996). Convicted but innocent: wrongful convictions and public policy. Thousand Oaks: Sage Publication.

Ish- Shalom, A. (2012). Police Investigation as an Instrument in Preventing Miscarriage of Justice. In R. Peled-Laskov, E. Shoham and M. Carmon (Eds.), Wrongful Convictions: Philosophical, Psychological and Organizational Aspects ( $\mathrm{p}$. 331-351). Tel Aviv: Perlstein-Ginossar Publications.

Jackiw, L. B., Arbuthnott, K. D., Pfeifer, J. E., Marcon, J. L., \& Meissner, C. A. (2008). Examining the cross-race effect in lineup identification using Caucasian and $F$ irst Nations samples. Canadian Journal of Behavioural Science, 40, 5257.

http://dx.doi.org/10.1037/0008-400x.40.1.52

Jackson, J. L., Granhag, P. A. (1997). Truth or fantasy: the ability of barristers and laypersons to detect deception in children's testimony. In J. F. Nijboer \& J. M. Reijntjes (Eds.), Proceedings of the first world conference on new trends in criminal investigation and evidence (pp. 213-220). Netherland: The open university of Netherlands.

Kassin, S. M. (1997). The psychology of confession evidence. American Psychologist, 52, 221- 233. http://dx.doi.org/10.1037/0003-066X.52.3.221

Kassin, S. M. (2015). The Social psychology of false confession. Social Issues and Police Review, 9, 25-51. http://dx.doi.org/10.1111/sipr.12009

Catz, O. (2012). Ethnic Bias in Eye Witness Testimony. In R. PeledLaskov, E. Shoham and M. Carmon (Eds.). Wrongful Convictions: Philosophical, Psychological and Organizational Aspects (p. 205-228). Tel Aviv: Perlstein-Ginossar Publications.

Keijser, J. W., Lange, E. G. Evianne, G. M., \& Wilsem, J. A. (2014) Wrongful convictions and the Blackstone ratio: an empirical analysis of public attitudes. Punishment \& Society, 16, 32-49. http://dx.doi.org/10.1177/1462474513504800

Kimberley, A. C., Leach, A.M. (2015 A.). After innocence: perceptions of individuals who have been wrongfully convicted. Legal \& Criminological Psychology, 20 (1), 147164. http://dx.doi.org/10.1111/lcrp.12018

Kimberley, A. C., Leach, A.M. (2015 B.). Stigma and wrongful convictions: all exonerees are not perceived equal. Psychology, Crime \& Law, 21, (2), 172-185. http://dx.doi.org/10.1080/1068316X.2014.951645

Kitai, R. (2003). The Importance of Positive Possession of Innocence, Its Role and Nature in Previous Procedures for Ruling in Criminal Law. Law Sheets, 3(2), 405-461.

Konvisser, Z. D. (2012). Psychological consequences of wrongful conviction in women and the possibility of positive change. DePaul Journal for Social Justice, 5(2), 221-294.

Koessler, S., Engler, H., Riether, C., \& Kissler, J. (2009). No retrieval-induced forgetting under stress. Psychological Science, 20, 1356-1363. http://dx.doi.org/10.1111/j.1467-9280.2009.02450.x

Koppl, R., \& Sacks, M. (2013). The Criminal Justice System Creates Incentives for False Convictions. Criminal Justice Ethics, 32, 126- 162. http://dx.doi.org/10.1080/0731129X.2013.817070

Leo, R.A. (2009). False confession: causes, consequences, and implications. The Journal of the American Academy of Psychiatry and the Law, 37, 332-343.

Leo, R.A., \& Deborah, D. (2010). From false confession to wrongful conviction: Seven psychological processes. The Journal of Psychiatry \& Law, 38, 9-56. http://dx.doi.org/10.1177/009318531003800103 
Lernau, H. (2001). Reforms in Detention Laws for Investigative Purposes in Israel. Doctoral thesis, submitted to the Institute of Criminology, Jerusalem: The Hebrew University of Jerusalem.

Lernau, H., Sela, N., Finkelstein, H. \& Rabinovitch, Y. (2012). Watershed: Between Guilt and Innocence. In R. PeledLaskov, E. Shoham and M. Carmon (Eds.). Wrongful Convictions: Philosophical, Psychological and Organizational Aspects (p. 277-314). Tel Aviv: Perlstein-Ginossar Publications.

Levy, M. (2015). The Danger of Wrongful Convictions in Israel, Their Principal Causes and Proposals for Their Reduction - in the footsteps of the book by Boaz Sangero Conviction of Innocent Persons in Israel and Worldwide: Causes and Solutions.

MacCrimmon, M. (2001). What is common about common sense? Cautionary tales for travelers crossing disciplinary boundaries. Cardozo Law Review, 22, 1432-1460.

Manning, P. (1997). Police work, The social organization of police work. (Second edition). Prospects Height, III.: Waveland Press Inc.

Mautner, M. (1993). The Decline of Formalism and the Rise of Values in Israeli Law. Tel Aviv: Maagalei Dat Publishers.

Mautner, M. (1998). Common Sense, Legitimacy, Coercion: On Judges as Storytellers. Criminal Law, 7, 11-76.

Mautner, M. (2006). On Uncertainty in Law and Some of its Implications. Law and Administration, 9, 223-259.

Meissner, C. A., \& Brigham, J. C. (2001). Thirty years of investigating the own-race bias in memory for faces: A meta-analytic review. Psychology, Public Policy, and Law, 7, 3-35. http://dx.doi.org/10.1037/1076-8971.7.1.3

Mizrahi, C. (2003). What Do Law, Investigation of the Truth and Plea Bargains Have in Common? Criminal Law, 8, 627-639.

Nahari, G. (2012). Individual Differences Between Judges in Determining the Credibility of Testimony. In R. Peled-Laskov, E Shoham and M. Carmon (Eds.). Wrongful Convictions: Philosophical, Psychological and Organizational Aspects ( $\mathrm{p}$. 229-239). Tel Aviv: Perlstein-Ginossar Publications.

Nahari, G., Glicksohn, J., \& Nachson, I. (2009). Do textual features affect credibility judgment? It all depends on who is the judge. Applied Cognitive Psychology, 23, 288-295. http://dx.doi.org/10.1002/acp.1529

Packer, H. (1968). The limit of the criminal sanction. Stanford: Stanford University Press. Wiley \& Sons.

Ramsey, R.J., \&. Frank, J. (2007). Perceptions of Criminal Justice Professionals Regarding the Frequency of Wrongful Conviction and the Extent of System Error. Crime and Delinquency, 53, 436-470. http://dx.doi.org/10.1177/0011128706286554

Redlich, A. D., Summers, A., \& Hoover, S. (2010). Self-Reported false confession and false guilty pleas among offenders with mental illness. Law and Human Behavior, 34, 79-90. http://dx.doi.org/10.1007/s10979-009-9194-8

Risinger, M. (2007). Innocents convicted: an empirically justified factual wrongful conviction rate. Journal of Criminal Law \& Criminology, 97(3), 761-806.

Salzberger, E. (2000). On Professional and Ethical Aspects and Things Beyond the Law - Reflections on the Start of Academic Year 5759. Law and Administration, 5, 409-416.
Sangero, B. (2005). Confession as a Basis for Conviction - Could the "Queen of Evidence" Be the Empress of Wrongful Convictions. Law Sheets, 4, 245-278.

Sangero, B. (2014). Convictions of Innocent Persons in Israel and Worldwide. Causes and Solutions. Tel Aviv: Resling Publishers.

Sangero, B., \& Halpert, M. (2012). Beware - Mistakes Under Scrutiny! On the Need for Regulation in the Area of Scientific Evidence and Condemnation of the Possession of the Credibility Draft Law as an Instrument of Enforcement. In R. Peled-Laskov, E. Shoham and M. Carmon (Eds.). Wrongful Convictions: Philosophical, Psychological and Organizational Aspects (p. 55-93). Tel Aviv: Perlstein-Ginossar Publications.

Sangero, B. \& Kreminitzer, M. (1999). Retrial - Dream or Reality? On Perception of Justice in Coping with the Finiteness of Law. Law Leaves, 1, 97-164.

Shechory, M. (2012). Biases in Interrogation: Stereotypes and Suggestiveness Among Police Investigators and Citizens in Israel. In R. Peled-Laskov, E. Shoham and M. Carmon (Eds.). Wrongful Convictions: Philosophical, Psychological and Organizational Aspects (p. 53-175). Tel Aviv: PerlsteinGinossar Publications.

Sheck, B., Neufeld, P., \& Dwyer, J. (2000). Actual Innocence. New York: Doubleday Random House, Inc.

Shoham, E. (2010). The Dark Side of the Sun. Beer Sheva: BenGurion University of the Negev.

Skagerberg, E. M., \& Wright, D. B. (2008). Manipulating power can affect memory conformity. Applied Cognitive Psychology, 22, 207-216. http://dx.doi.org/10.1002/acp.1353

Wells, G. L., \& Olson, E. A. (2001). The other-race effect in eyewitness identification: what do we do about it? Psychology, Public Policy, and Law, 7, 230-246. http://dx.doi.org/10.1037/1076-8971.7.1.230

Wells, G. L., \& Olson, E. A. (2003). Eyewitness testimony. Annual Review of Psychology, 54, 277-295. http://dx.doi.org/10.1146/annurev.psych.54.101601.145028

Wildeman, J., Costelloe, M., \& Schehr, R. (2011). Experiencing Wrongful and Unlawful Conviction. Journal of Offender Rehabilitation, 50, 411-432. http://dx.doi.org/10.1080/10509674.2011.603033

Yehosha-Stern, S. \& Carmon, M. (2012). False Confessions Psychological Aspects in the Work of the Police Investigator. In R. Peled-Laskov, E. Shoham and M. Carmon (Eds.). Wrongful Convictions: Philosophical, Psychological and Organizational Aspects (p. 115-134). Tel Aviv: PerlsteinGinossar Publications.

Zelig, E. \& Nachshon, Y. (2012). Biased Conceptions in Police Investigation. In R. Peled-Laskov, E. Shoham and M. Carmon (Eds.). Wrongful Convictions: Philosophical, Psychological and Organizational Aspects (p. 177-204). Te Aviv: Perlstein-Ginossar Publications.

Zemrion- Helek, D. (2012). Miscarriages of Justice in Investigations in the Context of Preventing the Suspect's Rights. In R. PeledLaskov, E. Shoham and M. Carmon (Eds.). Wrongful Convictions: Philosophical, Psychological and Organizational Aspects (p. 243-275). Tel Aviv: Perlstein-Ginossar Publications.

DOI: http://dx.doi.org/10.6000/1929-4409.2015.04.16

(c) 2015 Peled-Laskov and Shoham; Licensee Lifescience Global.

This is an open access article licensed under the terms of the Creative Commons Attribution Non-Commercial License (http://creativecommons.org/licenses/by-nc/3.0/) which permits unrestricted, non-commercial use, distribution and reproduction in any medium, provided the work is properly cited. 